\title{
Compilation of Quranic Verses Related To Visual Function
}

Noor Ezailina Badarudin ${ }^{1}$, Yazlin Yazid ${ }^{1}$, Siti Aishah Binti Md Halim ${ }^{1}$, Hasbullah Mohammad ${ }^{2}$

${ }^{1}$ Dept. of Optometry and Visual Science Kuliyyah of Allied Health Science, International Islamic University Malaysia (IIUM) Kuantan.

${ }^{2}$ Kulliyyah of Islamic Revealed Knowledge and Human Sciences, IIUM Gombak

\begin{abstract}
Islam provides a comprehensive way of life where the revelations bestowed by Allah from the Quran and Hadith cover all aspects that leads to a well-balanced life. This study compiles all the Quranic verses related to visual functions which may serve as a reference for Muslims as well as non-Muslim primary eye care practitioners during their patients' treatment and consultation. A website named "Search Truth" on http://www.searchtruth.com/was used as a tool to identify the Quranic verses related to visual function by typing in the keywords "eye/eyes", "see", "light", "sight" and "vision" in the search boxes provided in the website. The program embedded in the website then listed the Quranic verses based on their English translation containing the respective keywords. The listed Quranic verses and their translations were verified manually using the Holy Quran Tafseer. The frequency of Quranic verses for each chosen keyword was determined. There were 34 Quranic verses related to visual function and could be explained scientifically. The frequency of Quranic verses related to visual function under the classification of "eye/eyes", "light", "see", "sight" and "vision" were 15, 8, 3, 7 and 1 respectively. The fundamentals of visual functions may be explained scientifically based on the Quranic verses.
\end{abstract}

KEYWORDS: eye(s), see, light, sight, vision

\section{INTRODUCTION}

The human visual system is a precious gift whereby the eyesight bestowed by Allah upon us allows the daily activities to be conducted easily and efficiently. We are entrusted to use this gift wisely to bring us closer to Allah as His vicegerents. Allah reminds us in the Quran to be thankful for all the senses that we have, "It is He, Who has created for you (the sense of) hearing (ears), sight (eyes), and hearts (understanding). "Yet, only few of you are grateful" (23:78). According to Prophet Muhammad (SAW), "Allah The Almighty said, 'If I take away the eyesight of a slave of Mine and he shows patience and seeks My reward, then I shall reward him with nothing less than paradise,". ${ }^{5}$ People with affected eyesight may have difficulties to conduct their daily activities. However, with knowledge, patience and determination, they may be able to lead normal lives; and as a result will be rewarded by Allah. With our God's given pair of eyes, we will learn to appreciate His creations by observing our surroundings. Our pair of eyes is one of the vital senses in life and extremely essentials for survival. The visual functions involve many interdependent complicated processes in order for us to perceive the things we see.

Corresponding author:

Noor Ezailina Badarudin

Department of Optometry and Visual Science, Kuliyyah of Allied Health Science, International Islamic University Malaysia, Jalan Sultan Ahmad Shah, 25200 Kuantan Email:ezai@iium.edu.my
The human visual system comprises three main organs: the eye, the optic nerve bundle and the visual cortex of the brain. ${ }^{17}$ The objects we see emit light rays which enter our cornea (the transparent outermost layer of our eyes) and then pass through to the pupil. The iris (the coloured portion surrounding the pupil) regulates the amount of light entering the pupil by changing the pupil size. The light rays then pass through the crystalline lens which changes shape to enable the light to be refracted on to retina, a thin layer of tissue that contains millions of tiny light-sensing nerve cells. ${ }^{16}$ These nerve cells will convert the light stimulus into electrical impulses which then be transmitted by the optic nerve to the brain that produces the images we see. Thus, all things that we can see is actually the reflection of light that serves as a proof of the greatest creation of our Creator as stated in the Holy Quran, "Allah is the Light of the heavens and the Earth" (24:35).

According to the second edition of Oxford Advanced Learner's Dictionary of Current English, "light" is defined as opposite of dark which makes things visible whilst "eye" is the organ of sight and the word "sight" is defined as the power of seeing. ${ }^{7}$ In the first edition of Dictionary of Synonyms and Antonyms, the synonyms of "sight" are "vision" and "see". ${ }^{15}$ Vision is composed of many simultaneous functions known as visual functions. ${ }^{8}$ The different components of the visual image can form depth perception, colour perception and motion perception. 8 
There are limited writings on visual functions which refer to the Quran and Hadiths. Several publications by scholars had covered various aspects of science by referring to or supported by the Quran and Hadiths but none had focused exclusively on the visual function. For instance, water is pointed out as the origin of all life based on the verse "We made every living thing from water. Will they not believe?" (21:30) which is later supported by a scientific finding on cells, the origin of all living things, which are mostly made up of water. ${ }^{6}$ Thus, this qualitative study aims to compile all the Quranic verses related to visual function by referring to the words "light", "eye/s" and "sight (and its synonyms)"; which allows their frequency to be identified. The compiled words will later be associated with scientific based on visual functions, in order to prove how these divine revelations may serve as a reference for Muslim and interested nonMuslim primary eye care practitioners in treating their patients. This compilation may enable readers to obtain stronger faith by associating the divine revelations and the creation of sight in which we should be thankful for.

\section{METHODS}

\section{Study design}

This is a descriptive and qualitative study in which text document are being analysed (Al Quran) and sorted into categorical based on the keywords chosen.

\section{MATERIALS}

1. Quran -The Quranic verses related to optometry and eyesight are identified by referring to the words "light", "eye/s" and "sight" and its synonyms which are "see" and "vision".
2. "Search Truth" website on http:// www.searchtruth.com/ - Acts as a tool to ease the finding of the related Quranic verses.

Search for the Quranic verses involving the words "light", "eye/s" and "sight" (and its synonyms) was performed in the "Search Truth" website. Each word is filled in the provided search box in the website. The program embedded in the website will then list the related Quranic verses based on their English translation. The authenticity of the listed verses presented in the website was verified manually by referring to the Holy Quran. Verses containing words related to visual functions are listed where their frequency and numerical distribution are presented in Table 1.

\section{RESULTS}

Approximately $7.3 \%$ of the chosen words related to the visual function are shown in

Table 1 Numerical Distribution of words related to visual functions in the Quran

\begin{tabular}{cccc}
\hline Words & $\begin{array}{c}\text { Scientific } \\
\text { related }\end{array}$ & $\begin{array}{c}\text { Non- } \\
\text { scientific } \\
\text { related }\end{array}$ & Frequency \\
\hline Eyes & 15 & 65 & 80 \\
Light & 8 & 58 & 66 \\
See & 3 & 220 & 223 \\
Sight & 7 & 66 & 73 \\
Vision & 1 & 23 & 24 \\
Total & 34 & 432 & $\mathbf{4 6 6}$ \\
\hline
\end{tabular}

There are several words related to visual functions which may be explained with scientific proofs as presented in Table 2.

Table 2 Examples of Scientific References proofs and supporting Quran verses on visual functions

\section{Related Quranic Verses}

Al-Balad:90 Have We not made for him two eyes (to see).

\section{Scientific References}

Physiology of the eyes that allows human to attain binocular vision in order for us to perceive depth of perception. ${ }^{14}$

Both eyes are able to perceive image to create binocular single vision and thus establishing good stereopsis in which is useful in judging distance and carrying out minor daily tasks. Detection, resolution and discrimination become easier.

Eye-hand coordination also becomes easier with both eyes. ${ }^{11}$

Coordination of tears secretion related to emotions. There are certain stimuli that activate the efferent parasympathetic and sympathetic nerves which innervate the lacrimal gland and conjunctival goblet cells to secrete tears. ${ }^{1,14}$ 
Yusufa: 84 And he turned away

from them, and said: My sorrow for Joseph! And his eyes were became opaque and filled (with tears) on account of the grief, then he repressed (grief)

An-Nahl:77 And Allah is the unseen of the heavens and the earth.

And the matter of the Hour is but as a blinking of the eye or it is nearer still. Surely Allah is Powerful over all things.

Al-An'am: 103 Vision cannot comprehend Him, and He comprehends (all) vision; and $\mathrm{He}$ is the Knower of subtleties, the Aware

Al-Baqarah 17: Their parable is as the parable of one who kindles a fire, but when it illumines all around him, Allah takes away their light, and leaves them in darkness - they cannot see.

Al-Maidah 83: And when they hear what has been revealed to the Messenger you see their eyes overflow with tears because of the truth they recognize. They say: Our Lord, we believe, so write us down with the witnesses

Yusuf 93: Take this shirt of mine and cast it before my father's face - he will come to see. And bring to me all your family

Az-Zumar21: Seest thou not that Allah sends down rain from the sky, and leads it through springs in the earth? Then He causes to grow, therewith, produce of various colours: then it withers; thou wilt see it grow yellow; then He makes it dry up and crumble away. Truly, in this, is a Message of remembrance to men of understanding.
The presence of whitish opacity in the eyes was thought to be cataract. This is because Yusuf's father was old and prone to get cataract (senile cataract). Although, in this verse, Yusuf's father was blind after grieving and crying for Yusuf's loss, there is no scientific fact that relates excessive cry can cause blindness. ${ }^{13}$

This verse shows how fast Allah can decide something to happen within a blinking of an eye. A blink of an eye takes approximately 300 to 400 milliseconds. ${ }^{10}$

We definitely cannot see our Creator because He creates us with limited visual ability. We can only see the things that are within the wavelength of $400 \mathrm{~nm}$ to $700 \mathrm{~nm}^{4}$

It is hard to perceive our surrounding in darkness because the sensitivity of the retina is low when a person first enters a dark room. Although the retinal sensitivity will increase in time, our vision will still not be as good as how we see in bright illumination. ${ }^{2}$

Coordination of tears secretion related to emotions. There are certain stimuli that activate the efferent parasympathetic and sympathetic nerves which innervate the lacrimal gland and conjunctival goblet cells to secrete tears. ${ }^{1,14}$

It was thought that the shirt cast on Yusuf's father's face had sweat. The component in the sweat was believed to be able to cure the cataract. Dr. Abdul Basit had immersed cloudy lenses taken from the cataract surgery into the sweat and observed the transparency of the lenses improved. He then created anti-cataract eye drop which had received two international patents from The European International Patent in 1991 and the American in 1993. However, there is no legal paper written about it. The eye drop is also not commercialized. ${ }^{3}$

Light is made up of many colours. And a normal trichromat may differentiate between colours. ${ }^{9,18}$

\section{CONCLUSION}

Based on the chosen words, the anatomy and physiology of the eye may be scientifically described in the Quran, which includes the chronology of the creation whereby the visual sensory is formed after the hearing sensory formation has taken place. The formation of tears by the lacrimal functional unit, the importance of binocularity in image perception and eye movement as well as the characteristics of light which consists of colours are also mentioned in the verses. The importance of light and contrast sensitivity as a requirement for a clear vision is not left out. The opacity of the eye lens as the example of an ocular disease is also stated. The destinies of all human have already been decided by the Almighty but the possibilities of changes on these destinies may take place if He wishes so, in a blink of an eye which takes about 300-400milliseconds. We therefore suggest that the fundamentals of visual functions may be explained scientifically based on the Quranic verses. 


\section{REFERENCES}

1. Provine R Emotional tears and NGF: a biographical appreciation and research beginning. Archives Italiennes De Biologie. 2011;149:269-274.

2. Agarwal S, Agarwal A, Apple D Textbook of ophthalmology. New Delhi: Jaypee Brothers Medical Publishers; 2002.

3. Al Ghazal $\mathrm{S}$ The medical miracles of the holy quran [online]. Islamicmedicine.org. 2004. Available at: http:/www.islamicmedicine.org/ medmiraclesofquran/medmiracleseng.htm. Accessed July 10, 2017.

4. Brill T Light, its interaction with art and antiquities. New York: Plenum Press; 1980.

5. Khan M. The translation of the meanings of sahih al-bukhari Saudi Arabia: Dar Ahya Us-Sunnah; 1976.

6. Alberts B, Bray D, Hopkin K, Johnson A, Lewis J, Raff $M$ et al. Essential cell biology. USA: Garland Science; 2013.

7. Hornby AS, Wakefield H Oxford Advanced Learner's Dictionary 2nd ed. London: Oxford University Press; 1963.

8. Dowling $\mathrm{J}$ Neurons and networks: an introduction to behavioral neuroscience. USA: Harvard University Press; 2001.

9. Evans A Seeing color, it's my rainbow, too: an introduction to color vision. Auburn CA: CVD PUB; 2003.

10. Harbour J Lean human performance improvement. 1st ed. Florida: CRC Press; 2014.

11. Howard I, Rogers B Binocular vision and stereopsis. New York: Oxford University Press; 1995.

12. Ibn Al-Hajjaj A The english translation of sahih muslim. Riyadh: Maktaba Dar-us-Salam; 2007.

13. Khurana A Ophthalmology. New Delhi: New Age; 2003.

14. Levin L Adler's physiology of the eye. Edinburgh: Elsevier/Sounders; 2011.

15. Manser $M$ The wordsworth dictionary of synonyms and antonyms. Ware: Wordsworth Reference; 1998.

16. Acharya U Rajendra, Ng Y, Suri J Image modeling of the human eye. Norwood, Mass.: Artech House; 2008.

17. Remington L Clinical anatomy of the visual system. Saint Louis: Elsevier Health Sciences; 2011.

18. Roorda A, Williams D The arrangement of the three cone classes in the living human eye. Nature [online]1999 ;397:520-522. Available at: https: / /www.ncbi.nlm.nih.gov/

pubmed/10028967 Accessed June 7, 2017. 